\title{
“ZE CEETY PAYS"
}

\section{BY HAROLD A. CAPARN}

Not very long ago I sat on a bench in one of the New York City parks. Nearly opposite on another bench sat a happy and shortish and stoutish family eating lunch. You could see they were a family, they were so much alike. There were "poppa" and "momma" and several children from about 26 inches to 31 inches high. They all smiled. Why wouldn't they smile? It was a beautiful day, they had had a good lunch, and they didn't have to clear away after them.

Presently poppa gave one of the children a pasteboard box of the kind that Iwantanother biscuits come in. He took it and proceeded to tear the paper cover slowly into eleventeen bits and let the wind blow them in eleventeen different directions. Meantime, poppa looked on and smiled benignantly.

Then I thought of the way they pick up papers in the parks. You have seen how they do it. An oldish sort of man comes along with a spiked stick and a bag. He stabs each piece of paper separately and puts them all into the bag. In this way, he can pick up quite a number of pieces in a day.

Then I thought of what it costs to pay this man and all the other men who pick up papers that people ought to pick up for themselves, or that never ought to be scattered around. And I remembered the South Parks in Chi- cago, where it costs them $\$ 28,000$ a year to pick up papers! Think of what one could buy with all this money in the way of swimming pools, or gymnasiums, or tennis courts, or other things really worth while!

So I thought it was time to say something, and I went up to him and began: "My friend"-

(It seems a little queer that if you address some people as "My friend" they get rather angry, while some others seem to like it. It seems to me to show a nice disposition to be glad to be told that you are somebody's friend.)

"My friend," I said, "don't you think it's a mistake to let that boy tear up that paper? Don't you know that every piece has to be picked up, and that you and I help to pay for it?"

But he looked at me and smiled cheerfully. "Ah, no!" he said, "it is olright! Ze ceety peeck him up; we no pay."

"Yes, but," I persisted, "don't you know what the city is? It is you and I and everybody else. We all help to pay the taxes. All this work raises the taxes and helps to make rent and groceries and clothes cost more."

"Ah, no!" he replied, "you do not onderstand! We no pay! Ze ceety pay."

So I gave it up. I couldn't make him see that he and I were helping to pay for picking up those bits of paper. 